\title{
CREATING AN ENGLISH COMPUTER GAME AS AN INTERACTIVE MATERIAL IN TEACHING ENGLISH TO YOUNG LEARNER (TEYL)
}

\author{
Aprilian Ria Adisti \\ State Institute for Islamic Studies (IAIN) Salatiga \\ aprilian adisti@yahoo.com
}

\begin{abstract}
This study aims at explaining the interactive materials that were needed in Teaching English to Young Learner, creating an English computer game into an interactive material, and examining the effective of the implementation of an English computer game as an interactive material in Teaching English to Young Learner to the first-grade students of elementary school. The study used Research and Development (R\&D) adapted from Hutchinson and Water (1987:53-56) and by Borg and Gall (1985). The study had seven stages, they were: (1) conducting a need analysis of the first-grade students, (2) writing the course grid such as lesson plan and map of interactive material, (3) developing preliminary form of English computer game, (4) preliminary field testing by English teacher, English learning expert, and ICT learning expert, (5) revising the English computer game, (6) trying out, and (7) writing the final draft of the use of English computer game for Teaching English to Young Learners. The result of the study showed that students got better achievement in learning English. It could be seen from the result between pretest and post-test using t-test formula. The result showed $t$ value $>t$ table; $7.165>2.021$, it meant that there was a significant difference between pre-test and post-test. The post-test was higher that pre-test. The mean of pre-test was 65.2 while the mean of post-test was 87.44. It was also strengthened by the result of the interview which concluded that students liked learning English through this interactive material.
\end{abstract}

Keywords: Teaching English to Young Learner, an English computer game, interactive material

\section{INTRODUCTION}

English is an international language. Indonesian students learn English as foreign language. English is introduced for the first time for students in junior high school before 1994. They learnt English from the very beginning level, such as the introduction of vocabularies, simple grammar, etc. Since the need for mastering English becomes higher every time, nowadays, the English subject is given from the elementary school to senior high school levels, even from the first grade students of elementary school. 
Teaching English to Young Learner (TEYL) means teaching children in the first-grade of elementary school. TEYL is considered as an important way to develop children English skill in the future. The teachers need special treatments to young learner because sometimes they feel enthusiastic, but sometimes they also do not care about anything. That is why the teacher should introduce children in learning English through attractive method in order to raise their motivation and enthusiasm in learning English. One of them is by developing interactive English material that is designing an English computer game to make children interested in learning English.

The advancement of Information and Communication Technology (ICT) play a significant role in learning process. Teaching English without supported by interactive material, is considered as left behind. One kind of interactive material in teaching English is by designing an English computer game. Basically, children like learning trough playing. An English computer game is software that is designed for play and fun in learning English. By playing it, children are expected to be more interested in learning English. They may not be aware that they are even learning English. In their minds they are simply playing a game. Therefore, an English computer game as a part of technology can be used to raise the cihildren enthusiasm in learning English.

Teaching English to Young Learner (TEYL) can use English computer game as an interactive material for students. By playing game, student learn about vocabularies that are played in the game. Since the purpose of teaching English in elementary school level is to introduce English as an International language to students, so the most important thing for teacher in TEYL is introduce vocabularies first to the students. Vocabularies are the main aspect of language. Slatterly and Willis (2001) proposed the characteristics of young learners under seven years old in learning vocabularies;

a. They acquire through hearing and experiencing lots of English, in much the same way they acquire first language.

b. They learn things through playing; that are not consciously trying to learn new words or phrases.

c. They love playing with language sounds, imitating, and making funny noises.

d. They are not able to read and write in L1; important to recycle language through talk and play.

e. Their grammar will develop gradually on its own when exposed to lots English in context. 
Some studies agree that technology can be incorporated into Teaching English to Young Learner. Deng (2006) observed 45 students and carried out a four months experiment by teaching subjects in a traditional way during the first two months and then teaching students via games in the last two months. The results of the experiment between game teaching and nongame teaching indicate that it is beneficial to use games to promote language proficiency and vocabulary acquisition.

Besides, Brian A Briggs (2010) conducted the study about the use of technology to increase word recognition ability to kindergartens. The treatment group used digital cameras to define the environment around them, while the control group had no exposure to the technology. The result showed that in the control group scored higher in word recognition retention by at least $60 \%$ after four weeks of the study. He suggested that the use of technology throughout the curriculum would be a benefit for children in learning English. Of course, the result of his study proved that Teaching English to Young Learner through technology can motivate students in learning English.

In this present research, I focus to compare the research conducted by Deng (2006) and Brian A Brigg (2010) in some aspects. The first aspect, Deng (2006) observed some students who taught by traditional way and those who taught by game in learning English but he did not use computer game, while Brian A Briggs (2010) conducted the research to some students who taught English used technology, that was digital camera. In this research, however, I only focus to apply computer game as interacting material in Teaching English to Young Learner. The second aspect as the novelty aspect, I focus to create English computer game as interactive material in Teaching English to Young Learner. I also use Research and Development (R\&D) as the methodology in creating English computer game as interactive material in Teaching English to Young Learner, especially to the first grade of elementary students.

A computer game is software that is designed for play and fun. The game is constructed with certain rules and instruction to achieve specific goals usually through several levels. In facts, people or children spend hours to play and finish a computer game. It indicates that computer game is very engaging and attractive. Teachers can use this chance to teach vocabulary 
to students. By using computer game, students are expected to be more interested in learning English especially learning vocabulary through a computer game.

Vocabulary is important aspect in learning English. According to Cameron (2010:72), vocabulary is central to the learning of a foreign language at primary level. In addition, David Nunan (1991:118) stated that the development of rich vocabulary is an important element in the acquisition of a second language, include young learners. Based on the statements before, it is implied that vocabulary is one of the language skill elements that has an important role for young learners in learning languages. Teachers should teach students how to use vocabulary to convey their ideas, teaching, and knowledge. In general, teaching vocabulary especially for young learners is not easy. Thus, teachers need more creativity in teaching vocabulary to young learners.

As mentioned above, the use of English computer game can encourage students to enrich their vocabularies. They can learn through play. English computer game is considered as an interactive material for teaching vocabularies to the first-grade students of elementary school. When it is used appropriately, it can be a very valuable resource in Teaching English to Young Learner (TEYL).

\section{RESEARCH METHOD}

In this study, I used Research dan Development (R\&D) method. Based on the above background, I propose to put forward the following questions:

(1) Which interactive materials are needed in Teaching English to Young Learner?

(2) How can an English computer game be developed into an interactive material for Teaching English to Young Learner?

(3) How effective is the implementation of an English computer game as an interactive material in Teaching English to Young Learner?

\section{Objectives of Study}

The objectives of this study were to explain the interactive materials that are needed for Teaching English to Young Learner to the first-grade students of elementary school, to design and develop an English computer game into an interactive material, and to examine the effective 
of the implementation of an English computer game as an interactive material in Teaching English to Young Learner to first-grade students of elementary school.

\section{Research Procedures}

Based on the purpose of this study, that is to develop a finished product that can be used effectively in an educational program, this study is classified as R \& D category (Borg, 1981:712). The major purpose of $R \& D$ is not to formulate or to test theory but to develop the effectiveness of a product for use in classes. Products produced by R \& D are generally quite extensive in terms of objectives, personnel, and time to completion. In this study, the subject of this study was an English computer game as an interactive material.

The subjects of the study are the interactive material, 25 first-grade students of SD IT Ulil Albab, English teachers, English lecturers as the teaching expert, and ICT learning experts. The research framework in this research is drawn below:

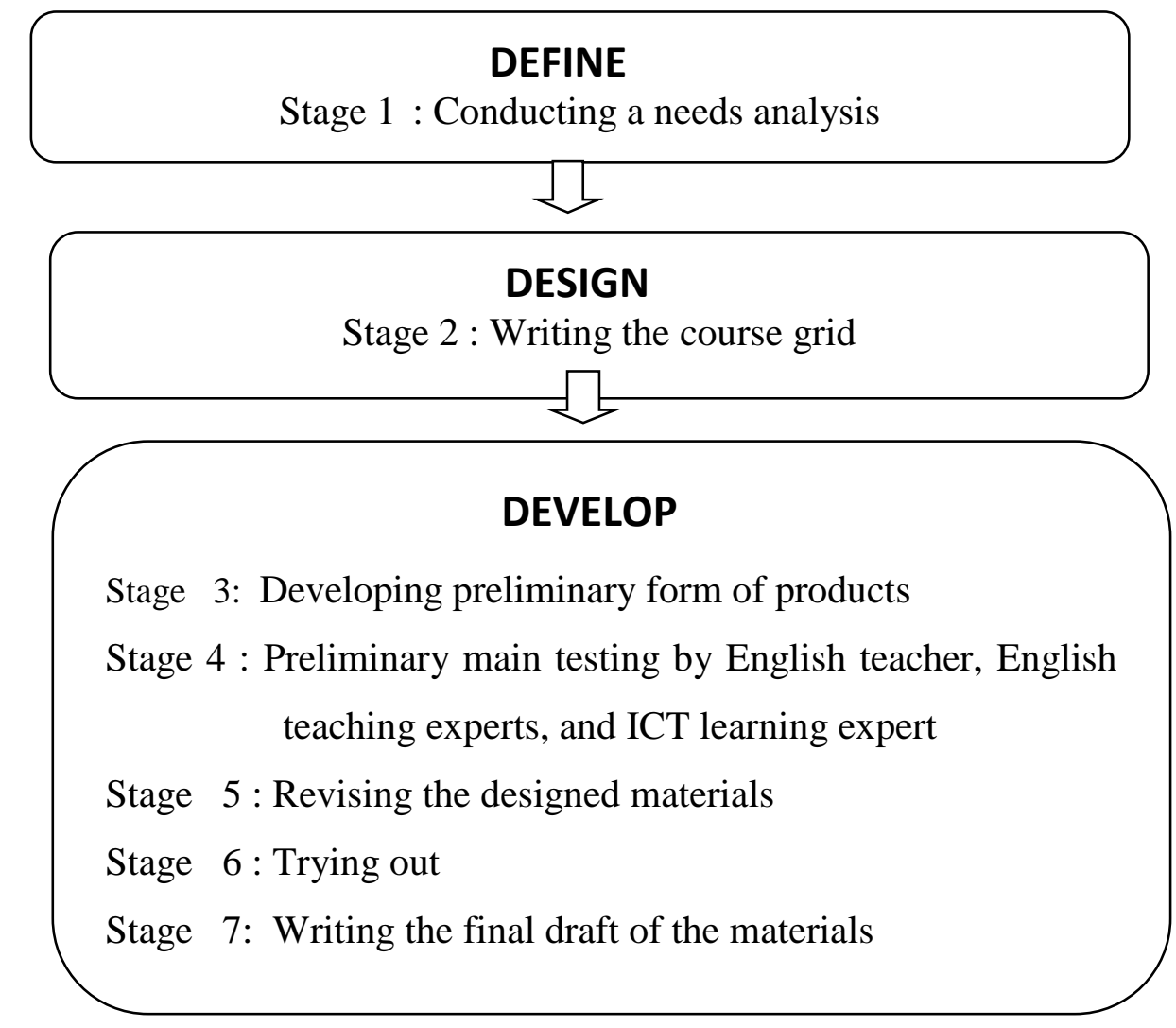


According to figure 1 above, there were seven stages. They were (1) Conducting a Needs Analysis, (2) Writing the Course Grid, (3) Developing Preliminary Form of Products, (4) Preliminary Main Testing by English Teacher, English Teaching Experts, and ICT Learning Experts, (5) Revising the Designed Materials, (6) Trying Out, and (7) Writing the Final raft of the Materials.

Instruments were needed to conduct the analysis. The type of instrument that was used to gather the data were observation, interview, questionnaire, and test. Observation was done in the first step. Then based on observation, I made the analysis about students' need and students' character by writing field notes, gathering documents, etc. Interview was given to support the main data. It was conducted for knowing students' need in learning vocabulary. Questionnaire was given in the forth stage that was given to develop the product. The tests were given to measure students' achievement in learning English. It was also used to indicate the effectiveness of using an English computer game as an interactive material in Teaching English to Young Learner.

\section{DISCUSSION}

This section discussed the result of the development. It consisted of seven sections. Those were explained in the following section in detaikl.

\section{Conducting Analysis}

It was the first step that was used to obtain the information of the learners' characteristics and needs in learning English. I started conducting a need analysis by interviewing the English teacher. The questions were about the English material, method of teaching English, and also the result of English learning during the teaching and learning process. Furthermore, I also interviewed some students about their opinion of learning English. This question was important to know what they wanted in learning English.

I started conducting a need analysis by interviewing the English teacher. The questions were about the English material, method of teaching English, and also the result of English laerning during the teaching and learning process. The schedule for English subject in SD IT Ulil Albab held twice in a week, that was Monday and Thursday. The duration was 35 minutes for 
each meeting. Before using this interactive material, students wew taught use a work sheet. Sometimes teacher also used pictures as media for teaching them. In SD IT ulil Albab, there were facilities like computer and laptop. But the teacher had never used them as a media for teaching.

According to teacher's opinion, students sometimes felt bored in learning English since the materials were not interesting. They just learned from the book. It made them learn English passively because they just read from the book then did the task. Some students said that English was boring subject. They did not want to learn English because they felt that this subject was very difficult to be learned. They preferred to learn other subject than to learn English lesson. They also said that they often forget about vocabulary that they had learned because they felt so difficult to memorize the vocabulary from the book. Based on the result of the interview from teacher and students, I took the conclusion that students need interactive material to support their eager in learning English.

\section{Writing the Course Grid}

This step was used as the guideline in developing the materials. In constructing the material, I made lesson plan that was used as guidance during English learning process. I also arranged the map of interactive materials which related to the Standard Competence and Basic Competence. The map of interactive material could be seen below;

Figure 2 Map of Interactive Material

\begin{tabular}{|c|c|c|}
\hline Skill & Objectives & Activities \\
\hline Listening & $\begin{array}{l}\text { Students are able to: } \\
\text { - Listen to the pronunciation } \\
\text { of the instructor about } 20 \\
\text { names of animals. } \\
\text { - Listen to the animal's } \\
\text { sound } \\
\text { Understand the simple } \\
\text { instructions in the English } \\
\text { game. }\end{array}$ & $\begin{array}{l}\text { Student operate their own computer to: } \\
\text { Listen and watch the video. } \\
\text { Guess the sound of the animals. } \\
\text { Click the pictures of animal based on } \\
\text { the instruction. }\end{array}$ \\
\hline Speaking & $\begin{array}{l}\text { Pronounce the new } \\
\text { vocabulary about } 20 \text { names } \\
\text { of the animals accurately. }\end{array}$ & $\begin{array}{l}\text {-Imitate the pronunciation of the } \\
\text { instructor in the English computer }\end{array}$ \\
\hline
\end{tabular}




\begin{tabular}{|lll|}
\hline \multirow{3}{*}{ Reading } & $\begin{array}{l}\text { game which they are playing. } \\
\text { animals } 20 \text { names of the }\end{array}$ & $\begin{array}{l}\text { Repeat the voice of the instructor. } \\
\text { - Answer the multiple choice questions } \\
\text { about the sound of the animals. }\end{array}$ \\
& - Match the words with the pictures of \\
& the animals. \\
Writing & $\begin{array}{l}\text { Type their name and grade } \\
\text { before play the English } \\
\text { computer game. }\end{array}$ & $\begin{array}{l}\text { Click the fonts in the computer before } \\
\text { playing the game. }\end{array}$ \\
\hline
\end{tabular}

Developing Preliminary Form of Products

In this step, the materials were developed based on the course grid that was written in the previous step. I started constructing computer game as an interactive material for students that was appropriated with lesson plan. The developing the materials were contains topic that was about animal, vocabulary focus, and also skills of English such listening, speaking, and reading and writing. The steps of developing the materials are:

\section{Determined the Topic}

According to the syllabus and lesson plan, the topic was about the animals. I just focus on one topic since the limited of time and it was also the request from the teacher. This topic had never be taught by the teacher before.

Determined vocabulary that would be taught

There were 20 names of the animals that had to be known bu students. Those names of the animals would be taught in the English computer game. At the end of the game, students would do quisses about them.

Designed the quizzes

There were three konds of quizzes in the English computer game such as: mention the name of the animals, guess the sound of the animals, and click the picture of the animals based on the instruction.

Arranged the lay out of the materials

Here designed the pictures of the animals, provides the video about animals, provides the animal's sound, provide the animations, record the dubber, provide the background and also the backsound of the game.

Preliminary Main Testing by English Teacher, English Teaching Experts, and ICT Learning Experts 
The development of the English computer game had validated by two English teachers, two English teaching expert, and two ICT learning expert. There were 15 questions below to each indicator in scoring sheets. To score each indicator, the experts had to put a check (V) mark on one of the available score columns in the table. The meaning of each score is; score 0 means totally lacking, score 1 means weak, score 2 means adequate, score 3 means good, and score 4 means excellent. The detailed of the judgment was shown below:

- The computer game that has designed is appropriate with Standard Competence and Basic Competence of the School Based Curriculum for the first grade students of Elementary level.

- The computer game that has designed fulfills the needs of the learners in level of the firstgrade students of Elementary level.

- The computer game that has designed eases students to learn English effectively.

- The computer game that has designed fits the background of students' age, culture and interest.

- Vocabularies that are used in computer game are appropriate with Elementary students' level.

- The computer game that has designed makes students more active in learning English.

- $\quad$ The quizzes in computer game are interesting and enjoyable for students.

- The instructions in every activity in computer game are clear for both the teacher and the students.

- The organization of the activity in computer game is clearly structured.

- The lay-out of the computer game is interesting for both the teacher and students.

- $\quad$ The pictures in the computer game attract students to play it.

- The audio and video in the computer game are clear to be listened and seen.

- The fonts in the computer game are easy reading for students.

- The pronunciation and intonation of the dubber are clear to be listened by students in the first-grade of elementary level.

- Generally, the computer game is easy to play for the students of the first-grade elementary level.

For the validation of the questionnaire above, the first English teacher judged excellent for questions point $1,2,3,4,5,6,7,8,10,11,12,13,15$ and good for questions point 9,14. For the second English teacher judged excellent for questions point 2,3,4,5,6,8,10,11,12,13,14,15 and good for questions point 1,7,9.

For the validation from the first English teaching expert judged excellent for all questions point 1,2,3,4,5,6,7,8,9,10,11,12,13,14,15. For the second English teaching expert judged excellent for questions $1,2,3,4,5,6,7,8,9,10,11,12,13,14,15$. 
For the validation from the first ICT learning expert judged excellent for the questions points $1,3,4,5,6,7,8,9,10,11,13,14,15$ and good for questions point 2,12. For the second ICT learning expert judged excellent for questions point 1, 2,3,5,6,8,11,13,14,15 and good for questions point 4,7,9,10,12.

According to the result of the questionnaire from experts' judgment, this interactive material was judged as valid product. We could see from the judgment that only two categories were chosen, they were good and excellent. It meant that English computer game could be used as interactive material in teaching vocabulary to the first-grade students of elementary school.

\section{Revising the Designed Materials}

In this step, the designed materials were revised as suggested by the feedback. There were some suggestions from 3 expert judgments. According to the result of the questionnaire, I made some revisions to the English game which included: (1) the materials, (2) the lay out (such as pictures, video, back ground of the game), (3) the quizzes in the game, (4) the voice of the dubber, and (5) the instructions of the game.

\section{Trying Out}

The try-out conducted to know whether the materials were appropriate or not for the students. Since the subject was the first level students of elementary school, I need the teacher's opinion and suggestion to judge whether this interactive material was appropriate or not for the students. Before I gave this interactive material for students, I played this English game to the teacher. I asked her whether this English game appropriate with material or not, and whether this English game was easy to play for the first level student of SD IT Ulil Albab or not.

Beside asked to the teacher, I also conducted try out to the students. One by one student tried play the game but not all section. I just wanted to make sure whether they could play the game easily or not. Surprisingly, the students were very enthusiastic with this activity. All of the students also did not feel difficulties to play the game. They played the game by themselves by clicked the mouse to operate it. Sometimes they asked about the meaning of the instruction but after I gave little bit explanation, they understood and continued play the game easily. It 
indicated that students could play the game, so for the next step I could use this game as an interactive material for teaching vocabulary for them, especially about the animal.

Before I gave an English computer game to the students, I conducted the pre-test first. The use of pre-test was important to measure the effectiveness of English computer game to improve students' ability in learning vocabulary. The result of pre-test would be compared to the result of the post-test after students learned vocabulary used English computer game as interactive material. According to the result between pre-test and post-test, the result of post-test was higher than pre-test. It could be seen from the mean of pre-test and post-test, which is 65.2 for pre-test and 87.44 for post-test. Students got improvement in post-test score after they used computer game as interactive material for learning vocabulary. All of the students passed the passing score. They did the quizzes well, and got better result than in pre-test. It indicated that an English computer game could be used as interactive material for improving students' vocabulary. Based on the result in post-test, the use of English computer game was considered effective to raise not only students' score but also students' eager in learning vocabulary.

\section{Writing the Final Draft of the Materials}

This step was done after revising the designed materials. The final result was the English learning materials for the first-grade elementary students. It was the fix English computer game that could be used as an interactive material for teaching vocabulary especially for the theme about animals.

During the research, the students enjoyed the activities. They played the game enthusiastically. All of the students were also said that they like playing Eglish game. They did not feel bored during the activity. The result of this interview indicated that the use of participation of English computer game as an interactive material could improve their eager in learning English. This statement was also be proven by the result of the post-test. Students got better achievement that pre-test. It could be seen in the comparison mean between pre-test and post-test. The mean from pre-test was 65.2 while the mean from post-test was 87.44 . by using ttest formula the result also showed that there was a significant achievement of the students after they learn vocabulary used this interactive material. Since $t$ value $>t$ table; $7.165>2.021$, it 
meant that there was a significant difference between pre-test and post-test group. The post-test was higher than the pre-test. Moreover, the implementation of these interactive materials could be used for improving students' achievement especially in learning vocabulary.

English computer game as an interactive material gave good contribution for teaching vocabulary to the first-grade students of elementary school. Based on experts judgment, this product was judged as valid product for teaching vocabulary. The teacher also gave opinion that this interactive material was so useful for her to teach vocabulary to students. As the result, the use of English computer game as an interactive material was ready to implement in teaching vocabulary to the first-grade students of elementary shool.

\section{CONCLUSIONS}

Before I conducted the research in SD IT Ulil Albab, the English lesson is always use English book and work sheet to be the materials. Based on the teacher's opinion, students need the interactive materials especially for learning vocabulary. Without used an interactive material, students would feel difficulty to memorize the vocabulary. Some of the students also said in the interview that they do no like learning English because for them English is a boring subject. The English computer game was considered as an interactive material that was used for students to improve their vocabulary. By playing the game, students learnt vocabulary enthusiastically. They could memorize the words while playing the game. This method was considered more effective than teaching them only use the English book and work sheet.

English computer game could be created to be an interactive material use seven stages; conducting a need analysis, writing the course grid, developing preliminary form of products, preliminary field testing by English teachers, English teaching experts, revising the designed materials, trying out, and writing the final draft of the materials.

English computer game was considered very effective to be implemented in teaching vocabulary to the first grade students of Elementary School. It could be seen from the comparison result between pre-test and ost-test. The mean of pre-test was 65.2 while the mean of post-test was 87.44. To know how the significant of the students' achievement, I calculated using $\mathrm{t}$-test formula. The result showed $\mathrm{t}$ value $>\mathrm{t}$ table; $7.165>2.021$, it meant that there was a significant difference between pre-test and post-test. The post-test was higher than pre-test. It 
indicated that students got significant achievement in learning vocabulary used English computer game as interactive material. Before students learnt English from the English computer game, their score was not good enough but since they learn vocabulary from the English computer game, their score was increase effectively. It was also strengthened by the result of the interview which concluded that students like learning through this interactive material. Finally, I recommended an English computer game as interactive materials for learning vocabulary, especially in Teaching English to Young Learner.

\section{REFERENCES}

Anyaegbu, Ruphina, et al. 2011. Serious Game Motivation in an EFL Classroom in Chinese Primary School. The Turkish Online Journal of Educational Technology, Issue 1, January 2012. [accessed 01/05/2016]

Borg, W. R. and Gall, M. D. 1983. Educational Research: An Introduction. NY: Longman Inc. Bredekamp, S., \& Rosegrant, T. 1994. Learning and teaching with technology. In J.L. Wright \& D.D. Shade (Eds.), Young children: Active learners in a technological age (pp.53-61).

Washington, DC: National Association for the Education of Young Children.

Briggs, A. Brian. 2010. Kindergarteners Using Digital Cameras to Label Their Surroundings to Increase World Recognition Abilities. Sacramento: California State University.

Brown, H. D. 2004. Language Assessment : Pronciples and Classroom Practice.. White Plains, NY: Pearson Education.

Brown, H. D. 2007. Teaching by Principles, An Interactive Approach To Language Pedagogy, Third Edition. White Plains, NY: Pearson Education.

Cameron, L. 2003. Challenges for ELT from the Expansion in Teaching Children. ELT Journal, issue 57: Oxford University Press. [accessed 07/05/2016]

Chuang, T., and Chen, W. 2007. Digital Games for Cognitive Learning : A Pilot Study. Journal of Scientific and Technological Studies. 41(1): 17-27.

Deng, Q. H. 2006. A study of using games in primary school English teaching. Unpublished master's thesis, Northwest Normal University, Shensu province, Chine.

Depdiknas. 2006. Kurikulum Tingkat Satuan Pendidikan Mata Pelajaran Bahasa Inggris SD/MI, SMP/MTs, SMA/MA. Jakarta: Departemen Pendidikan Nasional.

Deng, Q. H. 2006. A study of using games in primary school English teaching. Unpublished master's thesis, Northwest Normal University, Shensu province, Chine.

Gay, L. R. 1987. Educational Research : Competencies for Analysis and Applications, 3rd end. Ohio: Merril Publishing Company.

Hutchinson, T and Waters, A. 1987. English for Specific Purposes. Cambridge: Cambridge University Press.

Hammond, J. et al. 1992. English for Social Purposes. Sydney: Macquire University. Hartoyo. 2008. Individual Differences: In Computer-Assisted Language Learning (CALL). Semarang: Pelita Insani. 
Melisa, N. 1995. School Reform: What Role can Technology Play in a Constructivist Setting? Montgomery: A paper. Online. Availabe at http://pixel.cs.vt/edu/fis/techcons.html [accessed 02/05/2016]

Nunan, D. 1991. Language Teaching Methodology: A textbook for teachers. New York: Prentice Hall.

Prasetyo, F. H. 2007. Design and Aplikasi Media Pembelajaran dengan Menggunakan Macromedia Flash MX. Yogyakarta: Ardana Media.

Richard, J. C. 2002. Curriculum Development in Language Teaching. New York: Cambridge University Press.

Sanford, K., and Madill, L. 2007. Understanding the Power of New Literacies through Video Game Play and Design. Canadian Journal of Education. 30 (2): 432-455. [accessed 02/05/2016]

Shin, K. J. 2010. Ten Helpful Ideas for Teaching to Young Learners. Journal of English Teaching Forum (Vol. 44, No. 2). Available at http://exchanges.state.giv/englishteaching/forum/archieves.html. [accessed 22/05/2016]

Sokolik, M. 2001. Computers in Language Teaching in M.Celce-Murcia (Ed). Teaching English as Second or Foreign Language 3rd edition. New York: Heinle\&Heinle.

Sugiyono. 2011. Metode Penelitian Pendidikan. Bandung: Alfabeta.

Slatterly, M., \& Willis, J. 2001. English for Primary Teachers. Oxford: Oxford University Press. Thornbury, S. 2002. How to Teach Vocabulary. Essex: Longman.

Wang, C. X., et al. 2009. Integrating Second Life into EFL Program: Students' Perspective. Journal of Educational Technology Development and Exchane. 2(1): 1-16. [accessed 07/05/2016]

Wang, Ying, Jian, et al. 2011. Investigating the Impact of Using Games in Teaching Children English. International Journal of Learning and Development, issue 1, November 2011. Available at http://dx.doi.org/10.5296/ijld.vlid.118. [accessed 22/05/2016]

Williams, M.D., 2000. Introduction: What is technology integration. Integration Technology into Teaching and Learning: Concepts and Application. Prentice Hall : Singapore.

Yaworski, J. and Ibrahim, N. 2001. How to teach 1000 Vocabulary Words Using the Internet. A paper. Online. Available at http:findarticles.com/p/articles/mi_hb3247//is_2_31/ai_n28843731/ [accessed 27/05/2016] 